\title{
ANALISIS PERSEPSI KONSUMEN TENTANG LABELISASI HALAL PADA PEMBELIAN PRODUK MAKANAN IMPOR DALAM KEMASAN DITINJAU PERSPEKTIF EKONOMI SYARIAH DI KECAMATAN BENGKALIS KABUPATEN BENGKALIS
}

\author{
Iis Sutardi \\ Sekolah Tinggi Ilmu Ekonomi (STIE) Syariah Bengkalis \\ Email: sutardinovi@gmail.com
}

\begin{abstract}
ABSTRAK
Labelisasi halal merupakan pencatuman tulisan atau pernyataan halal pada kemasan produk untuk menunjukkan bahwa produk yang dimaksud berstatus sebagai produk halal. Tujuan penelitian ini yaitu untuk menganalisis persepsi konsumen tentang labelisasi halal pada pembelian produk makanan impor dalam kemasan ditinjau perspektif ekonomi syariah di Kecamatan Bengkalis Kabupaten Bengkalis dan untuk mengetahui faktor-faktor yang menentukan persepsi konsumen tentang labelisasi halal pada pembelian produk makanan impor dalam kemasan. Lokasi penelitian ini pada Kecamatan Bengkalis Kabupaten Bengkalis. Populasi penelitian ini berjumlah 442.211 orang dan sampel yang diperoleh sebanyak 100 orang dengan teknik sampel menggunakan rumus slovin yang kemudian diklasifikasikan dengan menggunakan simple random sampling. Pengumpulan data dilakukan dengan menyebarkan angket secara langsung kepada konsumen di Kecamatan Bengkalis Kabupaten Bengkalis dengan menggunakan skala likert kemudian diberi skor. Analisis data yang digunakan adalah menggunakan deskriptif kualitatif dengan menggunakan kategori pengukuran "Sangat Baik" pada kategori 81\%-100\%, "Baik" pada kategori 61\%-80\%, "Tidak Pasti" pada kategori 41\%-60\%, "Buruk" pada kategori 21\%40\%, dan "Sangat Buruk" pada kategori 0\%-20\%. Berdasarkan analis data dapat diketahui analisis persepsi konsumen tentang labelisasi halal pada pembelian produk makanan impor dalam kemasan ditinjau perspektif ekonomi syariah di Kecamatan Bengkalis Kabupaten Bengkalis dikatakan "Baik" dengan persentase $74 \%$ yang berada pada $60 \%-80 \%$. Adapun faktor yang menentukan persepsi konsumen tentang labelisasi halal pada pembelian produk makanan impor dalam kemasan ditinjau perspektif ekonomi syariah di Kecamatan Bengkalis Kabupaten Bengkalis yaitu faktor memilih. Dalam menentukan (mengambil dan sebagainya) sesuatu yang dianggap sesuai dengan kesukaan selera dan sebagainya. Sedangkan mengatur yakni tentang kepastian hukum yang berlaku tentang produk makanan yang berlabel halal. Menafsirkan apakah produk makanan impor dalam kemasan sudah berlabel halal MUI.
\end{abstract}

Kata Kunci: Persepsi, Labelisasi Halal, Produk Makanan Impor.

\section{PENDAHULUAN}

Persepsi konsumen berkaitan erat dengan kesadaran nya yang subjektif mengenai realitas, sehingga apa yang dilakukan seorang konsumen merupakan 
reaksi terhadap persepsi subjektifnya, bukan berdasarkan realitas yang objektif. Jika seorang konsumen berpikir mengenai realitas, itu bukanlah realitas yang sebenarnya, tetapi merupakan pikirannya mengenai realitas yang akan memengaruhi tindakan, seperti keputusan pembeli (Muflih 2006, 91-92).

Labelisasi obat dan makanan ditinjau dari pandangan masyarakat, maka kita akan berhadapan dengan kenyataan bahwa masyarakat, rakyat Indonesia sekitar $90 \%$ nya adalah konsumen muslim. Karenanya keamanan pangan bagi 90\% masyarakat Indonesia harus terpenuhi, maka secara tidak langsung akan menjadi relatif aman pula bagi selain konsumen muslim Indonesia. Bagi konsumen muslim, makanan yang aman tidak hanya sekedar terbebas dari bahaya fisik, kimia ataupun mikrobiologi, tetapi juga ada suatu unsur yang sangat hakiki, yaitu aman dari bahaya barang yang diharamkan dan diragukan. Kemanan, mutu dan gizi pangan sebagaimana amanat UU pangan No.70 tahun 1996 adalah merupakan upaya pemerintah dalam pembangungan pangan untuk memenuhi kebutuhan dasar rakyat Indonesia secara adil dan merata berdasarkan kemandirian dan tidak bertentangan dengan keyakinan masyarakat. (Adisasmito 2008, 2)

Bahaya keamanan pangan yang termasuk kategori berbahaya "yang haram dan atau yang meragukan" efek yang ditimbulkannya memang tidak tampak sebagimana efek dari cemaran kimia, fisik dan mikrobiologi yang langsung berimplikasi pada masalah kesehatan. Bahaya atas kategori halal ini berimplikasi pada ketenangan jiwa konsumen muslim dan sekali tercemar maka tidak dapat dielakan efek kerugiannya cukup besar baik financialmaupun kepercayaan konsumen terhadap prosuk tersebut. Kasus lemak babi pada tahun 1988 dan kasus ajinomoto menjadi suatu pengalaman buruk yang sulit dilupakan bagi konsumen muslim dan menjadi pelajaran yang cukup mahal bagi para produsen yang ingin berbinis di Indonesia. (Adisasmito 2008)

Pentingnya aspek legal labelisasi obat dan makanan, tekait dengan tuntutan konsumen yang terus meningkat khususnya mengenai aspek kehalalan ini. Secara hukum masalah ini telah diatur oleh pemerintah baik dalam undangundang pangan, undang-undang perlindungan konsumen maupun peraturan pemerintah yang mengatur secara lebih teknis. Sebelumnya anggapan atas labelisasi pada produk makanan merupakan hal yang menyulitkan dan prosedur yang bertele-tele bagi produsen, namun untungnya hal ini dapat diklarifikasi, dimana hanya kejujuran dan keterbukaanlah hal yang paling utama dalam labelisasi terhadap produk makanan ini. (Adisasmito 2008, 3)

Dengan adanya sertifikasi halal pada produk makanan yang menjadi konsumsi masyarakat, merupakan salah satu upaya perlindungan pemerintah terhadap $90 \%$ masyarakat konsumen muslim, namun selain dilihat dari sudut keyakinan masyarakat, labelisasi atas produk makanan dan obat yang beredar di masyarakat dapat menunjukan bahwa makanan dan obat tersebut juga layak dikonsumsi baik oleh kaum muslim maupun non-muslim. (Adisasmito 2008)

Dengan adanya pencatuman label halal konsumen muslim jadi terlindungi. Pencatuman label halal sarana informasi dari produsen ke konsumen mengenai produk yang akan dijualnya. Sehingga konsumen benar-benar mengetahui bahan-bahan apa saja yang digunakan, termasuk bahan tambahan yang tertera dikemasan. Pelabelan yang benar sesuai dengan ketentuan yang berlaku akan membentuk terciptanya perdagangan yang jujur dan bertanggung 
jawab. Sehingga akan memudahkan dalam pengawasan keamanan pangan dan melindungi konsumen dari persepsi yang salah. (Wikipedia 2017)

Maka dari itu, kehalalan suatu produk sangat berdampak terhadap persepsi konsumen dalam pembelian produk makanan impor, sebagai contoh produk impor dalam kemasan yang sudah menyebar luas di berbagai daerah, terutama di Kabupaten Bengkalis. Hal ini sangat layak apabila produk makanan impor dalam kemasan dijadikan sebagai bahan objek penelitian. Penelitian ini dilakukan untuk memperoleh informasi yang lebih jelas serta disertai bukti ilmiah mengenai bagaimana persepsi konsumen tentang label halal perlu dilakukan suatu penelitian ilmiah. Oleh karena itu, akan dilakukan penelitian dengan menjadikan masyarakat bengkalis kota sebagai studied population, karena masyarakat di Kecamatan Bengkalis dapat memahami dan mempertimbangkan tentang hukum yang berlaku mengenai labelisasi halal.

Tujuan penelitian ini dilakukan salah satunya adalah untuk menganalisis persepsi konsumen tentang labelisasi halal pada pembelian produk makanan impor ditinjau perspektif ekonomi syariah di Kecamatan Bengkalis Kabupaten Bengkalis, serta juta untuk mengetahui faktor-faktor yang menentukan persepsi konsumen tentang labelisasi halal pada pembelian produk makanan impor dalam kemasan.

\section{LANDASAN TEORI}

\section{Persepsi Konsumen}

Menurut Kamus Besar Bahasa Indonesia (KBBI) persepsi adalah tanggapan (penerimaan) langsung dari sesuatu; serapan dan proses seseorang mengetahui beberapa hal melalui panca indranya. ${ }^{1}$ Sedangkan menurut Deddy Mulyana mengatakan persepsi adalah proses internal yang memungkinkan kita memilih, mengorganisasikan dan menafsirkan rangsangan dari lingkungan kita, dan proses tersebut mempengaruhi perilaku kita. Persepsi juga merupakan pengalaman tentang objek, peristiwa, atau hubungan-hubungan yang diperoleh dengan menyimpulkan informasi dan menafsirkan pesan. (Rahmat 2005, 51)

Ada beberapa faktor yang mempengaruhi persepsi dan ekspektasi konsumen, yaitu (Gaspers 2001, 118):

1. Kebutuhan dan keinginan, yang berkaitan dengan hal-hal yang dirasakan konsumen ketika ia sedang mencoba melakukan transaksi dengan produsen/pemasok produk (perusahaan). Jika pada saat itu kebutuhan dan keinginannya besar, harapan atau ekspektasi konsumen akan tinggi, demikian pula sebaliknya.

2. Pengalaman masa lalu (terdahulu), ketika mengkonsumsi produk dari perusahaan maupun pesaing-pesaingnya.

3. Pengalaman dari teman-teman, di mana mereka akan menceritakan kualitas produk yang akan dibeli oleh konsumen itu. Hal ini jelas mempengaruhi persepsi konsumen terutama pada produk-produk yang dirasakan berisiko tinggi.

4. Komunikasi dan pemasaran, juga mempengaruhi persepsi konsumen. Orangorang di bagian penjualan dan periklanan seyogyanya tidak membuat

\footnotetext{
${ }^{1}$ http://kbbi.web.id/ diakses pada 15 Maret 2016.
} 
kampanye berlebihan melewati tingkat ekspektasi konsumen. Kampanye yang berlebihan serta secara aktual tidak mampu memenuhi ekpektasi konsumen akan member dampak negatif terhadap persepsi konsumen tentang produk itu.

\section{Produk Impor}

Menurut Pasal 1 Undang-Undang Republik Indonesia Nomor 33 Tahun 2014 Tentang Jaminan Produk Halal, produk adalah barang dan/atau jasa yang terkait dengan makanan, produk biologi, produk rekayasa genetik, serta barang gunaan yang dipakai, digunakan, atau dimanfaatkan oleh masyarakat. ${ }^{2}$

Pengertian impor adalah kegiatan memasukkan barang dari luar daerah Indonesia atau dikenal juga dengan sebutan daerah pabean ke dalam daeah Indonesia atau dalam daerah pabean. Maka dapat disimpulkan bahwa impor adalah setiap barang yang dimasukkan dari luar Negara Indonesia, baik secara legal maupun ilegal disebut juga barang impor (Brata 2014, 7).

\section{Label}

Label adalah bagian dari sebuah yang berupa keterangan (kata-kata) tentang barang tersebut atau penjualannya, misalnya produk "Caladine Lation" untuk mengatasi gatal karena alergi pada kulit. Dilabelnya tercantum informasi produk "Caladine Lation" tentang bera netto, komposisi bahan, cara pemakaian, cara penyimpanan, peringatan, nomor registrasi produk, perusahaan Caladine Lation, yaitu PT. Yupharin Pharmaceuticals, Bogor, Indonesia (Sunyoto 2012, 124)

\section{Halal}

Kata Halal adalah istilah bahasa Arab dalam agama Islam yang berarti "diizinkan" atau "boleh". Secara etimologi, halal berarti hal-hal yang boleh dan dapat dilakukan, karena bebas atau tidak terikat dengan ketentuan-ketentuan yang melarangnya (Qardhawi 2000, 5). Menurut Yusuf Qardhawi, halal adalah suatu yang mudah (diperkenankan), yang terlepas dari ikatan latangan, dan diizinkan oleh pembuat syari'at Islam untuk dilakukan (Qardhawi 2000, 13).

Menurut Undang-Undang Republik Indonesia Nomor 33 Tahun 2014 Tentang Jaminan Produk Halal, produk halal adalah produk yang telah dinyatakan halal sesuai dengan syariat Islam. ${ }^{3}$ Fatwa produk halal adalah fatwa yang di tetapkan oleh komisi fawa MUI, mengenai produk makanan, minuman, obat, kosmetik dan produk lainnya. Fatwa tersebut telah ditetapkan setelah dilakukan serangkaian pembahasan dalam rapat komisi fatwa yang didahului dengan laporan hasil auditing oleh LPPOM MUI dan peserta rapat memandang bahwa produk dimaksud tidak mengandung hal-hal yang dapat memandang bahwa produk dimaksud tidak mengandung hal-hal yang diharamkan, baik dari aspek bahan maupun dalam proses produksi.

\section{Labelisasi Halal}

Label halal adalah tanda kehalalan suatu produk. Sedangkan sertifikasi halal adalah pengakuan kehalalan suatu produk yang dikeluarkan oleh BPJPH

\footnotetext{
${ }^{2}$ Undang-Undang Republik Indonesia Nomor 33 Tahun 2014 Tentang Jaminan Produk Halal

${ }^{3}$ Ibid.
} 
berdasarkan fatwa halal tertulis yang dikeluarkan oleh MUI ${ }^{4}$. Sedangkan menurut Wiku Adisasmito dalam "Analisis Kebijakan Nasional MUI dan BPOM Dalam Labeling Obat dan Makanan", sertifikasi halal adalah fatwa tertulis MUI yang menyatakan kehalalan suatu produk sesuai dengan syariat Islam. Sertifikat halal ini merupakan syarat untuk mencantumkan label halal (Adisasmito 2008, 13).

Labelisasi halal mempunyai tujuan untuk memenuhi tuntutan pasar (konsumen) secara universal. Maka apabila tuntantan itu bisa terpenuhi, secara ekonomi para pebisnis Indonesia akan mampu menjadi tuan rumah dari segi produk yang dipasarkan. Tujuan lain yang sangat mendasar adalah melindungi akidah para konsumen terutama yang beragama Islam. Artinya dengan adanya labelisasi para konsumen muslim tidak lagi ragu dalam mengkonsumsi sesuatu yang dibutuhkan (Agustian dan Sujana 2013, 23).

Menurut Undang-Undang Republik Indonesia Nomor 33 Tahun 2014 Tentang Jaminan Produk Halal, menyatakan bahwa ada beberapa faktor yang mempengaruhi labelisasi halal sebagai berikut ${ }^{5}$ :

1. Perlindungan

Pengertian perlindungan adalah memberikan pengayoman kepada hak asasi manusia yang di rugikan orang lain dan perlindungan tersebut di berikan kepada masyarakat agar mereka dapat menikmati semua hak-hak yang di berikan oleh hukum yang berlaku.

2. Keadilan

Keadilan adlah dala bahsa sebenarnya adalah memberikan sesuatu pada tempatnya, adil bukan arti sama rata, melainkan memberikan sesuatu pada orang yang tepat sesuai dengan aturan yang berlaku dan yang memang menjadi haknya.

3. Kepastian Hukum

Kepastian hukum merupakan ciri yang tidak dapat dipisahkan dari hukum, terutama untuk norma hukum tertulis, hukum tanpa nilai kepastian akan kehilangan makna karena tidak dapat lagi dapat dijadikan pedoman perilaku bagi semua orang.

4. Akuntabilitas dan Transparansi

a. Akuntanbilitas merupakan istilah yang digunakan untuk mrnggambarkan tingkat pertanggungjawaban seseorang ataupun suatu lembaga tertentu yang berkaitan dengan system administrasi yang di miliki.

b. Sesuatu hal yang tidak ada maksud tersembunyi di dalamnya di sertai dengan ketersediaan informasi yang lengkap yang di perlukan untuk kolaborasi, kerjasama, dan pengambilan keputusan kolektif.

5. Efektivitas dan Efisiensi

Efektivitas dan Efisiensi adalah dua kata yang saling berhubungan dan saling berdekatan yang sering kita gunakan dalam tata bahasa sehari- hari terutama untuk anda yang berkecimpung dalam teknik, tata cara, optional dan prosedural.

6. Profesionalitas

Profesionalitas secara garis besar merupakn sipat yang berarti karakter kerja seseorang dalam menekuni profesinya atau juga kemampuan untuk bertindak secara professional. 


\section{METODOLOGI PENELITIAN}

\section{Jenis Penelitian}

Penelitian ini dapat digolongkan sebagai penelitian lapangan (Field Research) dengan pendekatan deskriptif kualitatif, untuk memaparkan data-data yang di dapat di lapangan kemudian menganalisisnya untuk mendapatkan kesimpulan dari penelitian ini.

\section{Lokasi Penelitian}

Penelitian ini dilakukan di Kecamatan Bengkalis Kota Kabupaten Bengkalis. Waktu pelaksanaan penelitian akan dilakukan sejak bulan November 2017 sampai dengan Juli 2018.

\section{Subjek dan Objek Penelitian}

Adapun subjek penelitian ini adalah konsumen di Kecamatan Bengkalis Kabupaten Bengkalis. Sedangkan objek dari penelitian ini adalah analisis persepsi konsumen tentang labelisasi halal dalam pembelian produk makanan impor ditinjau perspektif ekonomi syariah.

\section{Populasi dan Sampel Penelitian}

Populasi yang digunakan dalam penelitian ini adalah konsumen muslim di Kecamatan Bengkalis Kabupaten Bengkalis sebanyak 442.211 orang. Sampel dalam penelitian menggunakan rumus Slovin, sehingga sampel yang diteliti sebanyak 100 orang dan teknik pengambilan sampel dalam penelitian ini adalah menggunakan simple random sampling (metode penarikan sampel acak sederhana), yaitu suatu prosedur yang memungkinkan setiap elemen dalam populasi akan memiliki peluang yang sama untuk dijadikan sampel.

\section{Teknik Pengumpulan Data}

Untuk melengkapi data yang diperlukan dalam penelitian ini metode pengumpulan data yang digunakan adalah:

1. Angket atau kuesioner yaitu daftar pertanyaan yang diberikan kepada orang lain yang bersedia memberikan respons sesuai dengan permintaan pengguna, pengukuran variabel dilakukan dengan menggunakan skala lima alternatif pilihan (Skala Likert). Setiap variabel diberikan skor penilaian sebagai berikut (Riduwan 2014, 39):

Tabel 1

Skor Alternatif Pilihan Jawaban Angket

\begin{tabular}{|c|l|c|}
\hline No. & Pilihan Jawaban & Skor \\
\hline 1 & Sangat Setuju (SS) & 5 \\
\hline 2 & Setuju (S) & 4 \\
\hline 3 & Netral (N) & 3 \\
\hline 4 & Tidak Setuju (TS) & 2 \\
\hline 5 & Sangat Tidak Setuju (STS) & 1 \\
\hline
\end{tabular}

2. Wawancara

Wawancara adalah kegiatan mencari informasi atau keterangan atau pendapat melalui tanya jawab dengan responden. Tujuan wawancara adalah untuk mengungkapkan latar belakang, motif-motif yang ada di sekitar masalah yang 
diobservasi. Penelitian ini menggunakan wawancara semi terstruktur. Wawancara semi terstruktur termasuk dalam kategori in-dept interview di mana dalam pelaksanaannya lebih bebas dibandingkan dengan wawancara semi terstruktur. Wawancara ini sudah dipersiapkan pertanyaan tapi belum ada jawabannya. Tujuan dari wawancara ini adalah untuk menemukan permasahalan secara lebih terbuka di mana pihak yang diajak wawancara diminta pendapat dan ide-idenya (Sugiyono 2012, 233).

3. Dokumentasi

Metode dokumentasi adalah metode untuk mencari data mengenai hal- hal atau variabel yang berupa catatan, transkip, buku, surat kabar, majalah, prasasti notulen rapat, agenda dan lain sebagainya. Metode ini digunakan sebagai pelengkap guna memperoleh data sebagai bahan informasi yang berupa latar belakang Kecamatan Bengkalis Kabupaten Bengkalis serta data lain yang mendukung.

\section{Teknik Analisis Data}

Dalam penelitian ini data yang terkumpul diolah dengan deskriptif kualitatif. Dengan rumus frekuensi relatif sebagai berikut: (Martono 2010,12)

$p=\frac{f}{n} \times 100 \%$

keterangan :

$f=$ frekuensi yang sedang dicari

persentasenya $\mathrm{n}=$ jumlah

frekuensi/banyaknya individu

$\mathrm{p}=$ angka yang dicari presentasenya

Teknik pengukuran data penelitian menggunakan rumus lebar interval yaitu: (Hasan 2009, 44)

- $i={ }_{K}^{R} \mathrm{x} 100 \%$

Keterangan:

$\mathrm{R}=$ jangkauan (data tertinggi dan

terendah) $\mathrm{K}=$ Banyak kelas

(kelompok)

$i=\frac{100 \% \square 0 \%}{5}=20 \%$

Menurut (Hasan 2009) ada beberapa tahap dalam menentukan data presentase yang dikelompokkan sebagai berikut:

Sangat Baik Analisis persepsi konsumen tentang labelisasi halal dalam pembelian produk makanan impor ditinjau perspektif ekonomi syariah di Kecamatan Bengkalis Kabupaten Bengkalis kelompok $81 \%-100 \%$.

Baik Analisis persepsi konsumen tentang labelisasi halal dalam pembelian produk makanan impor ditinjau perspektif ekonomi syariah di Kecamatan Bengkalis Kabupaten Bengkalis kelompok

$61 \%-80 \%$. 
Sedang Analisis persepsi konsumen tentang labelisasi halal dalam pembelian produk makanan impor ditinjau perspektif ekonomi syariah di Kecamatan Bengkalis Kabupaten Bengkalis kelompok $41 \%-60 \%$.

Buruk Analisis persepsi konsumen tentang labelisasi halal dalam pembelian produk makanan impor ditinjau perspektif ekonomi syariah di Kecamatan Bengkalis Kabupaten Bengkalis kelompok $21 \%-40 \%$.

Sangat Buruk Analisis persepsi konsumen tentang labelisasi halal dalam pembelian produk makanan impor ditinjau perspektif ekonomi syariah di Kecamatan Bengkalis Kabupaten Bengkalis kelompok $0 \%-20 \%$.

Setelah hasil data dianalisis kemudian data tersebut direkapitulasi ke dalam bentuk tabel dan diakumulasikan sehingga diperoleh hasil dari analisis data.

\section{PEMBAHASAN PENELITIAN}

Berdasarkan hasil penelitian diketahui bahwa analisis persepsi konsumen tentang labelisasi halal pada pembelian produk makanan impor dalam kemasan ditinjau perspektif ekonomi syariah di Kecamatan Bengkalis Kota Kabupaten Bengkalis dikatakan "Baik" dengan persentase sebesar 74\%. Faktor-faktor yang mempengaruhi persepsi konsumen tentang labelisasi halal pada pembelian produk makanan impor dalam kemasan ditinjau perspektif ekonomi syariah di Kecamatan Bengkalis Kabupaten Bengkalis, yaitu:

Pertama, sebagian besar persepsi konsumen tentang labelisasi halal pada produk makanan impor dalam kemasan ditinjau perspektif ekonomi syariah sesuai dengan aspek memilih. Tanggapan tersebut terbukti dengan tingginya responden yang menyatakan Setuju dengan persentase sebesar 39,75\% ditunjukkan pada (angket No. 2) mengenai perlindungan konsumen pada produk makanan impor dalam kemasan berlabel halal masih belum optimal dengan persentase sebesar $45 \%$.

Kedua, sebagian besar persepsi konsumen tentang labelisasi halal pada produk makanan impor dalam kemasan ditinjau perspektif ekonomi syariah sesuai dengan aspek mengatur. Tanggapan tersebut terbukti dengan tingginya responden yang menyatakan Setuju dengan persentase sebesar 34,25\% ditunjukkan pada (angket No. 7) mengenai BPOM dan lembaga pemerintah lainnya selalu memberikan informasi produk makanan impor berlabel halal dengan persentase sebesar $47 \%$.

Ketiga, sebagian besar persepsi konsumen tentang labelisasi halal pada produk makanan impor dalam kemasan ditinjau perspektif ekonomi syariah sesuai dengan aspek menafsirkan. Tanggapan tersebut terbukti dengan tingginya responden yang menyatakan Sangat Setuju dengan persentase sebesar 32,75\% ditunjukkan pada (angket No. 12) mengenai profesional dalam membeli produk makanan impor berlabel halal dengan persentase sebesar $40 \%$. 
Dari pembahasan di atas dapat disimpulkan dari beberapa faktor-faktor yang menentukan persepsi konsumen tentang labelisasi halal pada pembelian produk makanan impor berlabel halal dalam kemasan ditinjau perspektif ekonomi syariah di Kecamatan Bengkalis Kabupaten Bengkalis yaitu faktor memilih dengan persentase sebesar 39,75\%.

Oleh Karena itu, upaya perlindungan hukum dapat memberikan kenyamanan bagi masyarakat untuk mengkonsumsi produk makanan impor dalam kemasan. Pasalnya dengan adanya labelisasi halal pada produk makanan impor dalam kemasan pada akhirnya mampu menarik apresiasi masyarakat (konsumen) dalam mengkonsumsi produk tersebut. Sertifikasi halal akan menjadi nilai tambah bahkan satu keharusan bagi produsen jika ingin produknya laku.

Sesuai dengan Undang-Undang Nomor 8 Tahun 1999 tentang Perlindungan Konsumen, kemudian Undang-Undang Nomor 18 Tahun 2002 tentang Pangan, dan Undang-Undang Nomor 33 Tahun 2014 tentang Jaminan Produk Halal yang telah berlaku pada tahun 2016 lalu, maka dapat ditarik kesimpulan bahwa upaya perlindungan hukum bagi konsumen oleh lembaga pada produk makanan impor yang tidak berlabel halal untuk mencapai kepastian hukum dan memberikan perlindungan bagi konsumen adalah:

1. Dengan dibentuknya Pengawasan Jaminan Produk Halal.

2. Dengan diterbitkan Undang-Undang yang mengatur tentang Labelisasi Halal dan juga Sertifikasi Halal.

3. Melakukan sosialisasi, himbauan atau penarikan produk yang melanggar ketentuan labelisasi halal

4. Dibentuknya Badan Penyelenggara Jaminan Produk Halal.

5. Dibentuknya Lembaga Pemeriksa Halal.

6. Dibentuknya Auditor Halal.

7. Terdapatnya Label Halal Resmi

8. Pemberian sanksi pidana bagi melanggat ketentuan yang diatur dalam Undang-Undang.

Terciptanya upaya hukum dalam melindungi konsumen pada produk makanan impor dalam kemasan yang tidak berlabel halal merupakan bagian dari bentuk aspirasi sebagian besar konsumen yang sadar akan pentingnya labelisasi halal, maka pemerintah dan lembaga terkait akan lebih terdorong dan powerfull dengan ditetapkannya suatu kewajiban sertifikasi halal, yang secara otomatis dengan adanya sertifikasi halal tersebut akan terwujud label halal berstandar resmi dan BPJPH terhadap produk makanan impor dalam kemasan di Kecamatan Bengkalis Kabupaten Bengkalis.

Berdasarkan hasil wawancara dengan konsumen di Kecamatan Bengkalis Kabupaten Bengkalis bahwa dengan adanya labelisasi halal pada pembelian produk makanan impor dalam kemasan dapat memberikan keamanan dan kenyamanan dalam mengkonsumsi produk tersebut. Sebagian konsumen pernah membeli produk makanan impor dalam kemasan yang tidak berlabel halal dan ada juga sebagian responden yang membeli produk makanan impor dalam kemasan yang berlabel halal. Selain itu, sebagian konsumen membeli produk makanan impor dalam kemasan seperti di Alfamart, Indomaret, Swalayan, dan Gerai Kecil lainnya. Pembelian produk makanan impor dalam kemasan dilakukan 1 sampai 5 kali dalam sebulan. Adapun makanan impor dalam kemasan yang sering dibeli untuk dikonsumsi seperti susu kaleng/kotak, kecap asin, kue otak-otak, kerupuk, 
cokelat, mie instan, Apollo, wafer, dan makanan kemasan lainnya. Konsumen yang menemukan produk makanan impor dalam kemasan yang tidak berlabel halal tidak akan membelinya, tetapi lebih memilih produk makanan impor dalam kemasan yang berlabel halal. Adapun produk makanan impor dalam kemasan yang tidak berlabel halal salah satunya yaitu snack/makanan ringan. Kendala yang dihadapi konsumen yaitu kurangnya pengetahuan konsumen tentang produk makanan impor dalam kemasan yang berlabel halal, kurangnya informasi dari pihak terkait tentang produk makanan impor yang tidak berlabel halal. Solusinya yaitu diharapkan peran pemerintah dan BPOM serta pihak terkait untuk menindak lanjuti dan mengawasi produk makanan impor dalam kemasan yang tidak berlabel halal dan memberi sanksi kepada produsen yang tidak memiliki izin label halal. Selain itu, diharapkan kepada BPOM dan pihak terkait untuk selalu memberi informasi dan mensosialisasikan kepada konsumen di Kecamatan Bengkalis Kabupaten Bengkalis akan pentingnya produk makanan impor dalam kemasan berlabel halal. ${ }^{6}$

Beberapa temuan produk makanan impor yang tidak berlabel halal tidak membuat konsumen putus asa untuk selalu memperhatikan dalam pembelian produk makanan impor yang berlabel halal. Peran pemerintah dan lembaga terkait dalam memberi perlindungan hukum sangat diharapkan bagi konsumen. Dengan adanya kepastian hukum dan perlidungan bagi konsumen, maka produk makanan impor dalam kemasan yang berlabel halal tidak diragukan ataupun ditakuti oleh konsumen. Maka dari itu, labelisasi halal pada produk makanan impor dalam kemasan sangatlah penting dalam memenuhi kebutuhan sehari-hari.

Kehadiran sebuah peraturan perundangan merupakan keniscayaan untuk menjamin kepastian hukum bagi setiap pencari keadilan untuk menjamin rasa aman, nyaman, dan tenang dalam kehidupan. Tanpa adanya perundangan yang berfungsi mengatur perlindungan secara khusus atas hak-hak dan kewajiban konsumen berpotensi akan mengundang kecurangan kalangan produsen yang akan melahirkan hak-hak konsumen. Sebab itu, kehadiran Undang-Undang Nomor 8

Tahun 1999 tentang Perlindungan Konsumen sudah barang tentu akan mempersempit ruang penyimpangan dalam dunia bisnis yang dapat merugikan berbagai pihak. Dan dengan perundangan ini maka akan memperjelas apapun yang menjadi hak dan kewajiban konsumen, sebagaimana juga apa yang menjadi hak dan kewajiban produsen.

Demikian juga dengan adanya kebijakan standarisasi halal yang sudah mulai digalakkan oleh pemerintah dengan tujuan agar komonitas muslim dapat terlindungi dari berbagai produk yang belum jelas status hukumnya. Baik yang berupa makanan, minuman maupun kosmetika atau produk lain yang bisa dikonsumsi oleh konsumen yang menurut ajaran agamanya terlarang untuk dikonsumsi. Adanya standarisasi halal tidaklah berarti pemerintah ingin memanjakan komunitas tertentu di negeri ini, karena kebijakan itu akhir-akhir ini juga digalakkan Negara non muslim sekalipun. Di negeri Kangguru, Australia, akhir-akhir ini telah banyak mengeluarkan produk-produk yang berlabel halal. Motif pokoknya adalah kepentingan bisnis karena konsumen yang dibidik adalah seluruh komunitas yang beragama keyakinan.

\footnotetext{
${ }^{6}$ Wawancara dengan Marlina di Kecamatan Bengkalis Kabupaten Bengkalis, pada hari Senin, 4 Juni 2018.
} 
Demikian pula negeri Jiran, dalam hal ini Malaysia yang mayoritas penduduknya sebagai penganut Islam telah lama mencanangkan produk halal untuk melindungi kepentingan konsumen dari pengguna segala macam produk yang dapat menganggu keyakinannya. Bahkan bangsa Malaysia bertekad ingin menjadikan negerinya sebagai pusat makanan halal di tingkat dunia. Sebuah ambisi konstruktif dalam upaya melindungi kepentingan konsumen yang patut menjadi contoh bagi Negara-negara berpenduduk muslim seperti Indonesia.

Apabila sebuah produk tanpa label halal, bisa terjadi komunitas muslim ragu mengonsumsinya sehingga menurut kalkulasi bisnis sudah barang tentu akan kurang menguntungkan. Sebaliknya, jika berlabel halal maka kecenderungan seluruh konsumen dengan beragam agamanya akan tetap mau mengkonsumsinya. Inilah kiranya yang dimaksudkan dengan pencantuman label halal akan jauh lebih menguntungkan dalam perspektif bisnis yang mengejar profit. Bukankah makanan halal itu sah-sah saja dikonsumsi oleh siapapun tanpa mengenal batas keyakinnya. Sebaliknya yang tidak halal dikonsumsi, niscaya akan dikonsumsi dari kalangan terbatas yang menurut keyakinannya tidak haram mengonsumsinya. Inilah sejatinya pentingnya labelisasi halal untuk setiap produk untuk memperluas daya jangkau penikmat sebuah produk yang akhir-akhir ini sudah mulai kritis dalam memilih berbagai jenis produk sebelum mengonsumsinya.

\section{KESIMPULAN}

Berdasarkan hasil penelitian, maka dapat ditarik kesimpulan mengenai analisis persepsi konsumen tentang labelisasi halal pada pembelian produk makanan impor dalam kemasan ditinjau perspektif ekonomi syariah di Kecamatan Bengkalis Kabupaten Bengkalis. Berdasarkan tujuan penelitian, maka kesimpulan hasil penelitian ini adalah sebagai berikut:

1. Dari hasil penelitian menyatakan "Baik", hal ini dapat dilihat dari hasil analisis data dengan persentase sebesar $74 \%$ atau akumulasi responden jawaban berada pada persentase $60 \%-80 \%$ dapat dinyatakan "Baik".

2. Faktor yang menentukan persepsi konsumen tentang labelisasi halal pada pembelian produk makanan impor berlabel halal dalam kemasan ditinjau perspektif ekonomi syariah di Kecamatan Bengkalis Kabupaten Bengkalis yaitu faktor memilih dengan persentase sebesar 39,75\%.

\section{DAFTAR PUSTAKA}

Adisasmito, Wiku. 2008. Analisis Kebijakan Nasional MUI dan BPOM dalam Labeling Obat dan Makanan. Depok: Departemen Administrasi \& Kebijakan Kesehatan Fakultas Kesehatan Masyarakat Universitas Indonesia.

Agustian, H. Eri dan Sujana. 2013 "Pengaruh Labelisasi Halal Terhadap Keputusan Pembelian Konsumen (Studi Kasus Pada Produk Wall's Conello). STIE Kesatuan. Jurnal Ilmiah Manajemen Kesatuan (JIMKES). Vol. 1, No. 2.

Brata, I Komang Oko. 2014. Panduan Praktis Ekspor Impor, Cet. 1. Jakarta: Raih Asa Sukses. 
Gaspers, Vincent. 2001. Ekonomi Manajerial: Pembuatan Keputusan Bisnis. Jakarta: PT. Gramedia Pustaka Utama.

Hasan, M. Iqbal. 2009. Analisis Data Penelitian Statistik. Jakarta: Bumi Aksara

Martono, Nanang. 2010. Statistik Sosial. Yogyakarta: Gava Media.

Muflih, Muhammad Muflih. 2006. Perilaku Konsumen Dalam Perspektif Ilmu Ekonomi Islam, Ed. 1. Jakarta: PT. Raja Grafindo Persada.

Qardhawi, Yusuf. 2000. Halal dan Haram dalam Islam. Jakarta: Rabbani Press Qardhawi, Yusuf. 2007. Halal dan Haram dalam Islam. Surakarta: Era Intermedia.

Rahmat, Jalaludin. 2005. Psikologi Komunikasi. Bandung: Remaja Rosda Karya Office.

Riduwan. 2014. Dasar-Dasar Statistika. Bandung: Alfabeta

Sugiyono. 2012. Metode Penelitian Kuantitatif Kualitatif dan R\&D. Bandung: Alfabeta.

Sunyoto, Danang. 2012. Dasar-Dasar Manajemen Pemasaran Konsep Strategi dan Kasus. Yogyakarta: CAPS

Undang-Undang Republik Indonesia Nomor 33 Tahun 2014 Tentang Jaminan Produk Halal

Wawancara dengan Marlina di Kecamatan Bengkalis Kabupaten Bengkalis, pada hari Senin, 4 Juni 2018.

Wikipedia. 2017 "LPPOM MUI", dikutip dari http://id.wikipedia.org/wiki/LPPOM_MUI pada hari Sabtu tanggal 09 September 2017

http://kbbi.web.id/ diakses pada 15 Maret 2016. 